\section{Repairing trust within teams after organizational change}

\author{
Tiina Kähkönen \\ School of Business and Management, Lappeenranta-Lahti University of Technology, \\ Lappeenranta, Finland
}

Repairing trust within teams

\begin{abstract}
Purpose - This study examines trust-repair practices at the team level after organizational change. Design/methodology/approach - A qualitative research approach was adopted, and data were collected from key informants through focus group discussions and interviews. The data analysis involved thematic coding and followed the structured procedure.

Findings - This study found that after organization change, trust can be repaired at the team level by improving team leaders' information sharing and knowledge in change management, and by enforcing communication, collaboration and ethical behaviour among team members.

Research limitations/implications - This paper makes three key contributions by (1) identifying trust violations in teams, (2) proposing trust-repair mechanisms and (3) extending the understanding of trust-repair and preservation at the team level following organizational change.

Practical implications - This paper provides practical information from a real-work context and can improve managers' understanding of active trust-repair.

Originality/value - This paper outlines active trust-repair mechanisms in an organizational change context and expands the current theory by presenting novel insights into organizational trust-repair at the team level. This study contributes to trust literature by proposing promising avenues for future trust-repair research.

Keywords Organizational change, Trust-repair practices, Teams, Knowledge management, Collaboration, Information sharing

Paper type Research paper
\end{abstract}

\section{Introduction}

Organizational changes, such as downsizings or other structural changes, have increased significantly. Organizations' internal crises, along with external societal crises, conflicts and even pandemics as at present with COVID-19, can quickly weaken an organization's performance. Organizational changes create a new situation throughout an organization and can affect uncertainty and feelings of vulnerability among employees (Kähkönen, 2020). Change also challenges trust among team members, can hinder efficient operations and impact team performance (Costa et al., 2017). The high importance of trust raises the question of how team leaders and other team members can repair trust in teams when organizations are facing many rapid changes (Morgeson et al., 2015).

On the theoretical side, several trust-repair models are proposed (Bachmann et al., 2015; Gillespie and Dietz, 2009; Lewicki and Bunker, 1996; Tomlinson and Mayer, 2009). Empirically, however, there is less research at the team level (Kim et al., 2006; Lewicki et al., 2016). Most of the scant research that does exist at that level has dealt with competence-based trust violations (Sverdrup and Stensaker, 2018). In addition, organizational trust-repair research at the team level has dominated mainly on laboratory experiments to measure the differences among a few trust-repair practices, for example, the effect of apology vs denial

(C) Tiina Kähkönen. Published by Emerald Publishing Limited. This article is published under the Creative Commons Attribution (CC BY 4.0) licence. Anyone may reproduce, distribute, translate and create derivative works of this article (for both commercial and non-commercial purposes), subject to full attribution to the original publication and authors. The full terms of this licence may be seen at http:// creativecommons.org/licences/by/4.0/legalcode

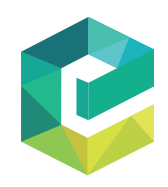

Received 15 November 2020

Revised 28 February 2021 Accepted 21 April 2021 
JOCM 34,5

958

(Kim et al., 2012). In this study, I adopt a multilevel approach used by Costa et al. (2017) that encompasses both individual- and team-level conceptualizations in order to reflect the dynamic nature of trust in teams. In addition, this research investigates trust-repair mechanisms in a change context using a qualitative research method, with the focus on integrity-based, benevolence-based and competence-based trust violations at the team level.

This study includes interviews and focus groups with 22 key informants, consisting of team members, union representatives and team leaders. The main contributions are (1) identifying trust violations in teams, (2) proposing trust-repair mechanisms and (3) extending the understanding of trust-repair and preservation at the team level following organizational change.

\section{Theoretical background}

One definition of interpersonal trust is "a psychological state comprising the intention to accept vulnerability based upon positive expectations of the intentions or behaviour of another" (Rousseau et al., 1998, p. 395). I adopt this definition at the team level as well (Lewicki and Brinsfield, 2017) because scholars researching trust in teams have largely proposed trust as a psychological state (Fulmer and Gelfand, 2012) that is affected by the complex interrelations among intentions, dispositions and expectations (Mayer et al., 1995; Rousseau et al., 1998). Mayer et al. (1995) identified three dimensions of trustworthiness: ability, benevolence and integrity (the ABI model) and I have adopted that same ABI model. The model suits well when team members' expectations regarding another member's competence, benevolence or integrity have not been met. I also adopted the multilevel approach used by Costa et al. (2017), which encompasses both individual- and team-level conceptualizations to reflect the dynamic and emergent nature of trust in teams. The approach treats trust within a team as based on the relationships among the individuals who comprise that team.

Dirks et al. (2009, p. 69) reported that trust-repair occurs "when a transgression causes the positive state(s) that constitute(s) the relationship to disappear and/or negative states to arise, as perceived by one or both parties, and activities by one or both parties substantively return the relationship to a positive state". This general definition of relationship repair can be used to understand trust-repair within teams and I adopted it for this study. This study focuses on trust-repair after organizational change at the team level, taking into account the individuals within a team, but it does not address trust-repair at the organizational level (e.g. employeremployee relationship). Further, this research focuses only on employee perspectives, rather than those of external stakeholders such as customers, suppliers, shareholders or regulators.

Next, I discuss the state of the art in conceptual and empirical research on employee trustrepair with a particular focus on empirical research at the team level. Trust in teams involves a continuous social process of sense-making (Weick, 1995), interpreting, signalling and reciprocating, which highlights the dynamic nature of trust including active trust (Giddens, 1990, 1994; Luhmann, 1979, 1988; Möllering, 2013). The conceptualization of active trust emphasizes the active role of organizational members in the constitution of trust (Gustafsson et al., 2020). Accordingly, maintaining high trust levels within a team requires deliberate and continuous action from team members. In teams, trust-repair seems to revolve around improving information sharing and social relations among team members (Sverdrup and Stensaker, 2018). Social exchange theory has been successfully applied in research on trust at the team level (Serva et al., 2005) and also applies to this research.

I carefully reviewed the previous literature in order to capture all relevant empirical studies on employee trust-repair. A systematic review of previous literature followed the structured literature review process proposed by Tranfield et al. (2003) and involving five stages. To ensure the literature search was comprehensive, I used two of the dominant databases in social sciences, Web of Science and Scopus (Falagas et al., 2008) and pre-defined 
criteria. In order to avoid possible selection bias, the screening and selection of the articles were verified independently by two researchers. After all those stages, 28 relevant articles were identified and five of those dealt with employee trust-repair at the team or group level are integrated and presented in Table 1.

At the team level, Kim et al. (2012) investigated apologies vs denial in the hiring context and they found that repairing trust is generally more difficult with groups than with individuals because groups can share their opinions in a way that can reinforce negative feelings. The same study also found that after competence-based violation groups were less trusting when trustees denied culpability, thus an apology was suggested. However, after integrity-based violation groups were less trusting when trustees apologized, because it confirmed guilt.

Pate et al. (2012) investigated a senior management team's attempt to regain trust through addressing workplace bullying. The study found that strong actions by the senior management, for example openly and honestly providing emotional support, had a significant effect on perceptions of bullying in the UK public sector, where organizational surveys had indicated a downward trend in trust in senior management teams, in parallel with growing concerns about bullying and harassment. Similarly, between middle managers and the top management in the hotel industry context, Webber et al. (2012) found that after competencebased trust violations, the perceived emotional support was significantly and positively related to trust in the top management.

In the change context Sverdrup and Stensaker (2018) found that increasing the quality of social exchange at work by renegotiating the psychological contract could help recover trust between the broader groups of senior management and employees. Sørensen et al. (2011) studied and analysed how trust dynamics developed over time in two Danish manufacturing firms affected by major change programmes. They found that organizational change creates uncertainty among employees and that strong management actions can rebuild trust in such situations. Thus, active attempts to protect trust can lead to positive trust outcomes but if low trust turns into distrust without any trust-repair practices, the result may be deadlock that both parties find difficult to break.

There are reasons to believe that little is known about how teams can actively repair trust after organizational change and after competence-, benevolence- and integrity-based trust violations. Thus, my aim is to develop an empirically informed theoretical understanding of how organizational trust-repair can be implemented by first identifying the violations and then asking the following question: Which active trust-repair mechanisms do team leaders and team members can use within teams after organizational change? Mayer et al. (1995)

\begin{tabular}{|c|c|c|c|}
\hline $\begin{array}{l}\text { Author(s) and } \\
\text { year }\end{array}$ & Methodology & Reason for the decline in trust & $\begin{array}{l}\text { Trust-repair responses } \\
\text { and types }\end{array}$ \\
\hline Kim et al. (2012) & $\begin{array}{l}\text { Laboratory } \\
\text { experiment }\end{array}$ & $\begin{array}{l}\text { Employees' previous errors in the } \\
\text { hiring context }\end{array}$ & Apology, denial (verbal) \\
\hline Pate et al. (2012) & Survey & $\begin{array}{l}\text { The founding principle of respect had } \\
\text { been contravened in an organization } \\
\text { (bullying, harassment) }\end{array}$ & $\begin{array}{l}\text { Emotional support } \\
\text { (verbal/substantive) }\end{array}$ \\
\hline $\begin{array}{l}\text { Sørensen et al. } \\
\text { (2011) }\end{array}$ & $\begin{array}{l}\text { Longitudinal } \\
\text { multimethod case } \\
\text { study }\end{array}$ & Major change programmes & $\begin{array}{l}\text { Strong management } \\
\text { actions (organizational } \\
\text { reforms) }\end{array}$ \\
\hline $\begin{array}{l}\text { Sverdrup and } \\
\text { Stensaker } \\
(2018)\end{array}$ & $\begin{array}{l}\text { Longitudinal } \\
\text { qualitative study }\end{array}$ & Strategic change & $\begin{array}{l}\text { Increasing the social } \\
\text { exchange quality } \\
\text { (substantive) }\end{array}$ \\
\hline $\begin{array}{l}\text { Webber et al. } \\
(2012)\end{array}$ & Survey & The lack of support & $\begin{array}{l}\text { Emotional support } \\
\text { (verbal/substantive) }\end{array}$ \\
\hline
\end{tabular}

\section{Repairing trust} within teams

959


JOCM 34,5

\section{0}

dimensions of trust as well as trust-repair practices identified in the current literature act as guiding principles in this study. My aim is with abductive analysis construct the best available explanation for the research problem (Dubois and Gadde, 2002).

My philosophical position in this study is post-positivism. The main difference of postpositivism to positivism is that it epistemological recognizes that we cannot be absolutely certain of truth when studying the behaviour of humans (Creswell, 2009). Post-positivism relies on the ontological position of critical realism (Guba and Lincoln, 2005) which assumes that there is a real and objective reality out there, but that our understanding of it is limited by human cognition and subjective views (Guba and Lincoln, 2005). Critical realism is useful in case studies because it is suitable for the analysis of complex entities, such as organizations and relationships of organizations (Easton, 2010).

\section{Methodology}

\subsection{Research approach}

This study was conducted in a non-profit organization in Finland. In the case organization downsizing took place in 2008, 2013 and 2015. In addition, technological and internal structural changes (e.g. new team and department divisions) have been ongoing. The views of the several staff groups are considered to ensure a multifaceted perspective on how organizational change has affected the teams. This study also captured the perspective of those employees who left the organization after the staff reductions because the treatment of exiting employees may affect team dynamics. An abductive research approach was chosen. This approach is a fruitful method when the goal of the research is to make discoveries and extend previous theory (Dubois and Gadde, 2002). I used previous theory as a pillar which provides guidelines, but previous theory does not explain all the perspectives within the specific change context under this study (Dubois and Gadde, 2002). An in-depth single case study was performed with qualitative data to discover the trust-repair practices utilized at the team level in the case organization. Case studies are particularly useful in organization studies and when the aim is to understand diverse social phenomena in real-life environments (Yin, 2003).

\subsection{Data collection and analysis}

The study used semi-structured focus group discussions and interviews as data sources. Six interviews were implemented and found useful because they allow the researcher freedom to follow up on different perspectives (Leavy, 2014). Three discussion groups were formed by inviting key informants. This approach ensured that information came directly from knowledgeable people and that the interviews and focus group discussions provided data and insights that could not be obtained by employing other methods (Tremblay, 1957). All key informants had worked in the case organization for a long time, at least ten years; thus, they had a long-term view of changes over time. What is more, the most significant changes were clearly remembered because the rate of change had accelerated in recent years.

Sixteen participants were divided into three internally homogeneous groups based on their work unit and hierarchical position. The focus group guide was pilot-tested on two informants within the target organization and adjusted accordingly. Two focus group discussions were conducted in May and one in June 2018. The first focus group included team members, the second included team leaders and the third included union representatives. Five to six participants from each group participated in the group-specific discussions.

The questions included the following examples: "If you have felt that your faith in one or more of these dimensions (ability, benevolence, integrity) deteriorated during or after change, indicate which dimension deteriorated at the team level" and "What do you think are the best acts, practices, or behaviors to exhibit when there is a need to protect or repair trust during 
and after change at team level?” Each focus group discussion lasted approximately $90 \mathrm{~min}$, for a total length of $264 \mathrm{~min}$. All the focus group discussions were recorded and fully transcribed, and the first was analysed with the aid of another researcher experienced in using focus groups.

Similar to the focus group approach, key informants were invited to participate in interviews (Tremblay, 1957). Four interviews were conducted in May and two in June 2018. These were semi-structured interviews, and had the same themes as the focus group discussions. Two informants were team leaders, one was a union representative and three were team members. Each interview lasted about 30-45 min, for a total of $214 \mathrm{~min}$. All interviews were recorded and fully transcribed. Data collection stopped when the same opinions began to recur, indicating a saturation point had been reached.

Next, the data analysis was implemented. Analysis involved thematic coding and followed an analytical structured process. First, the data arranged into first-codes, after this into second-order codes and finally aggregated into theoretical dimensions (Gioia et al., 2012). This method was justified because it is a straightforward analytical process that increased the credibility of qualitative research by clearly demonstrating the progression from raw data to theoretical dimensions (Zimmermann et al., 2015).

\section{Findings}

Table 2 illustrates the data analysis framework and identified trust violations. Lack of communication, incompetence of the team leaders and an absence of ethical behaviour and collaboration were the major problems cited in all respondent groups.

\subsection{Effective information sharing}

Lack of communication affected trust levels and caused both competence- and integritybased trust violations in teams. In some cases, participants were dissatisfied with their work

\begin{tabular}{|c|c|c|}
\hline First-order codes & Second-order themes & Aggregated dimensions \\
\hline $\begin{array}{l}\text { (1) Information provided by team leaders } \\
\text { was inadequate } \\
\text { (2) Team leaders avoided answering } \\
\text { questions }\end{array}$ & $\begin{array}{l}\text { Lack of information sharing } \\
\text { and communication }\end{array}$ & Lack of communication \\
\hline $\begin{array}{l}\text { Team leaders had not experienced in } \\
\text { change management } \\
\text { (1) There was a lack of team leaders' } \\
\text { experience } \\
\text { (2) Team leaders' supervisory work was } \\
\text { incompetent }\end{array}$ & $\begin{array}{l}\text { Lack of knowledge in change } \\
\text { management } \\
\text { Lack of leadership skills }\end{array}$ & $\begin{array}{l}\text { Incompetence of the team } \\
\text { leaders }\end{array}$ \\
\hline $\begin{array}{l}\text { (1) Dismissed team members were angry or } \\
\text { behaved improperly } \\
\text { (2) Team leader used power in an } \\
\text { unpleasant way }\end{array}$ & Lack of constructive behaviour & $\begin{array}{l}\text { Lack of ethical behaviour } \\
\text { and collaboration }\end{array}$ \\
\hline $\begin{array}{l}\text { (1) Team leaders did not to provide support } \\
\text { to dismissed team members } \\
\text { (2) Only colleagues provided emotional } \\
\text { support for dismissed team members } \\
\text { (3) Team leaders did not provide support for } \\
\text { team members }\end{array}$ & Lack of support & \\
\hline $\begin{array}{l}\text { Collaboration between team members was } \\
\text { not continuous }\end{array}$ & Lack of collaboration & \\
\hline
\end{tabular}

Repairing trust within teams 
JOCM 34,5

962

team's approach to implementing internal communication. The limitations of communication were especially reflected in the interactions between individual team members and the team leader, in which the former felt the latter did not provide enough information. One team member described: "Our team leader clearly avoided team members' questions". This was probably partly because the employer had given the team leaders guidelines to follow when discussing the situation with team members. The team leaders felt that this guidance had been quite well organized, but some also felt that they could not speak openly with their team members. When the parameters regarding what could be communicated to, or discussed with, team members remained unclear, some team leaders passed on information about the status of the process but communicated little else. One team leader stated, "It was a little unclear if one could say if a team members' job was safe, and then nothing was really related to anyone, and everyone was in a state of fear for a very long time." Accordingly, I propose the following: P1. Team leaders' effective information sharing can repair violated trust among team members after organizational change.

\subsection{Knowledge in change management}

Team leaders' incompetence in change management affected competence-based trust violations in the teams. All the informants in the focus groups agreed that none of the team leaders had experience of change management and lacked any training on the issue. Downsizing was a new situation in the case organization, and as one team member observed, "I think that team leaders did not have any change management experience". Ability to lead change did not matter previously in the case organization, but their absence was clearly visible in the downsizing context.

All the focus groups expressed how supervisory training should be continual. Many team leaders had only recently stepped into a new role, and also the downsizing situation was an entirely new one. Therefore, their skills in the downsizing situation were not as strong as they could have been. Team members expect team leaders to be able to handle change. Thus, effectively implemented management actions expressing the leaders' competence, skills and knowledge can protect team members' trust. In accordance with the findings, I propose the following: P2. Team leaders' knowledge of change management can repair violated trust among team members after organizational change.

\subsection{Ethical behaviour and collaboration}

A lack of ethical behaviour and collaboration were a major source of trust violations and caused benevolence-based trust violations in particular in teams. Constructive behaviour, and especially a benevolent attitude towards other team members, plays an important role in actors' evaluations of another party's trustworthiness. In a crisis, team members are frequently not fully capable of constructive behaviour. For example, some dismissed team members directed their anger at being dismissed at their colleagues. One team member said, "When she [colleague] came with the signed slip, I was a little taken aback when she asked me to explain why I got to stay and why she did not". Interviewees pointed out that cooperation among team members was not consistent. Team members felt that they were in the same situation as other team members during the changes, but at the same time the sense of competition seemed to intensify. Some team members remained silent, while others felt the need to discuss the changes. Dismissed team members and other team members worked together in the same office several months after downsizing because the redundant team members were required to work a six-month notice period. Many felt that the atmosphere was uncomfortable, and discussions were less open and positive than before. However, those team members able to continue open discussions protected the trust among team members more effectively than those who were unable to engage in such discussions. One team member 
stated, "It was just a terribly stressful time trying to work in the same room, and the other team member was in a bad mood".

Emotional support plays a significant role in change contexts, especially in team leaderteam member relationships. The data analysis revealed that in some team leaders were unable to provide emotional support. This was especially common in cases of dismissed team members; some team leaders admitted that facing employees who were to be dismissed was difficult, stressful and even a cause of anxiety because many dismissed employees wanted to know who had made the decision to dismiss them. One interviewed team member perceived the team leaders' support for dismissed team members as follows: "The team leaders really failed to provide support". One team leader viewed the situation similarly: "Humanity was forgotten after the dismissals in that in a way, those who had been in the building for 20 years became riffraff overnight". The union representatives agreed: "And yes, it was noticeable after the downsizing that team members would have required help in many instances; they would have needed support from their team leader. Team leaders did not realize that, and instead they even began to get scared to go among their team". Somewhat surprisingly, none of the dismissed interviewees stated that the support they had received from their own team leader was insufficient. Rather, they stated that other team members were incapable of giving emotional support to their dismissed colleagues. In fact, their immediate team leaders were described as quite empathetic. One dismissed team member was very surprised at how her colleagues reacted; some essentially stopped greeting her in the corridor, and this lack of empathy stung: "It felt really awful that for some colleagues it was apparently so difficult to face me that they were clearly trying to walk past me along the wall of the corridor". Another team member saw the matter differently in his own team: "Without support from colleagues, the dismissed ones would have been really alone”. Accordingly, I propose the following: P3. Ethical behaviour and collaboration between team members can repair violated trust within teams after organizational change.

\subsection{Summarized findings}

This study proposed a trust-repair model at the team level by, first, examining three types of trust violations: (1) lack of communication, (2) incompetence on the part of team leaders and (3) lack of ethical behaviour and collaboration. Second, the study identified mechanisms that can be used to repair trust: (1) effective information sharing, (2) knowledge in change management and (3) ethical behaviour and collaboration. The most significant ideas are shown in Figure 1, which presents the integrated trust-repair model at the team level after organizational change. This mean that when repairing team members trust, it takes place in two phases. Trust-repair phase 1 includes team members' feedbacks and then diagnosis about trust violations after change. Trust-repair phase 2 includes trust-repair mechanism identified and implemented.

Table 3 summarized extended findings at team/group level and theoretical contributions. After competence-based trust violations team leaders' knowledge of change management can repair violated trust among team members. Both, after integrity and competence-based trust violations team leaders' effective information sharing can repair violated trust among team members. After benevolence-based trust violations which may occur between all team members, ethical behaviour and collaboration between team members can repair violated trust within teams.

\section{Discussion}

Organizational changes have increased significantly and challenge trust among team members. This study aimed to understand how team leaders and other team members can
Repairing trust within teams

963 


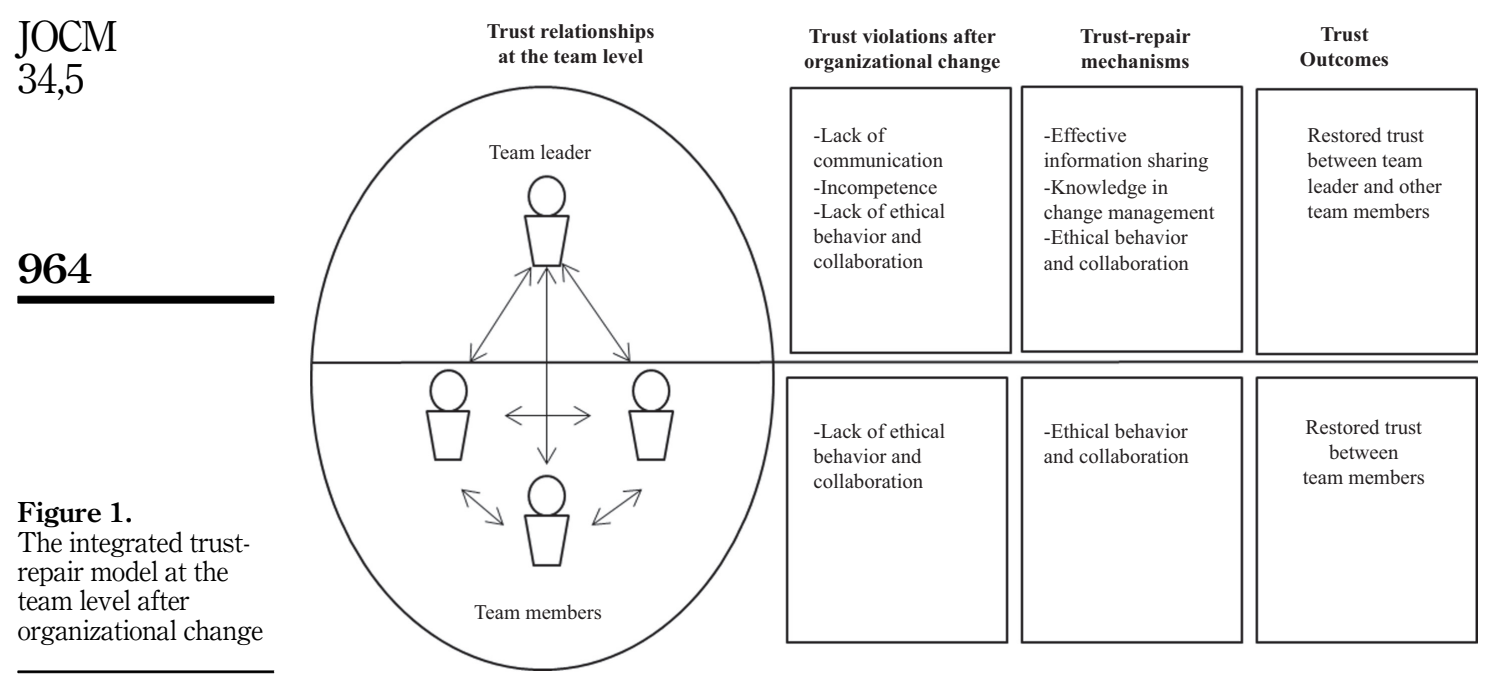

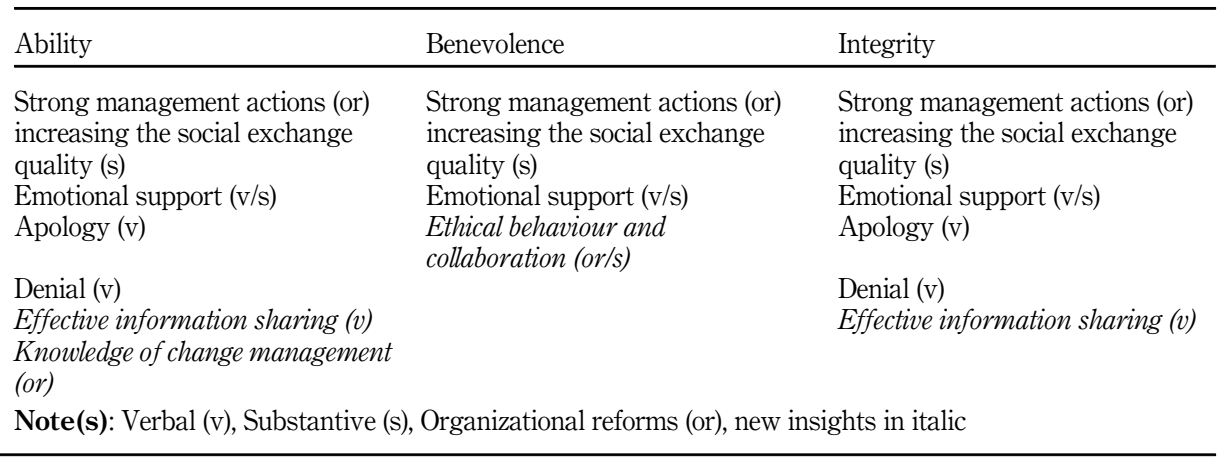

\section{Table 3.}

Summary of extended findings at team/ group level repair trust after changes. This research is theoretically valuable because despite previous research on building and repairing organizational trust, the understanding of how to repair trust within teams is still limited. This paper offers three key contributions to trust theory. First, it contributes to trust theory by advancing the understanding of trust violations at the team level. At that level, in situations of change, there may be competence-based, benevolence-based and integrity-based trust violations (Sørensen et al., 2011; Sverdrup and Stensaker, 2018).

Because change is usually organized by the top management (employer), employees expect the most significant of trust-repair actions to be implemented among the top management (Kähkönen, 2020). However, because organizations operate systematically, the effects of change also flow to the team level. It would appear that at the team level, the most impactful trust violations occur within individuals' social interactions. Negative verbal and behavioural expressions and actions, such as lack of collaboration and lack of ethical behaviour, cause trust violations among team members. Team leaders' incompetence regarding knowledge of change management also easily affects competence-based trust violations among team members. 
The second contribution is the integrated model of trust (Figure 1). Trust within a team demands continuous and successful social processes (Möllering, 2013) between team members, taking into account the dynamic nature of trust including active trust (Giddens, 1990, 1994; Luhmann, 1979, 1988). This means that a high trust level within a team requires active and continuous work by team members and trust-repair mechanisms to be introduced. I therefore define trust-repair mechanisms at the team level as "active and continuous interactive practices to restore team members' violated trust to a past state". Such acts require team members to show goodwill towards each other and to possess the desire to forget past violations by improving social exchanges with effective information sharing, ethical behaviour and collaboration. Based on the previous literature, researchers broadly accept separating trust violations according to trust dimensions and target trust-repair accordingly (Sørensen et al., 2011; Kim et al., 2012). By increasing their constructive voices and positive interactions, team members can help restore trust within a team (Six and Skinner, 2010). If team members are capable of ethical behaviour, including a benevolent attitude towards other team members, and can work together constructively even during changes, they can even avoid benevolence- and integrity-based trust violations and ensure trust remains at its existing level despite the change situation. This means that every team member needs to be heard and seen, and team members should also have the right to express their opinions regarding appropriate activities. All team members should feel that they are valued members of the team, regardless of education, position or role. In addition, employees in particular expected that team leaders possess conversation and interaction skills, support capabilities and the ability to take strong management actions that reflect honesty, benevolence and fairness (see also Sørensen et al., Webber et al., 2012). If a team leader has strong skills and the ability and knowledge to handle change, competence-based violations can be avoided. If a violation of trust has already occurred, additional efforts will be required. Increased, timely communication and increased team leader knowledge of change management can help restore a team member's trust in the team leader.

Kim et al. (2012) found that repairing trust is generally more difficult with groups than with individuals because group members can share their opinions in a way that can further reinforce negative feelings. Further, I suggest that repairing trust within a team after organizational change is always more difficult than protect existing trust during a period of change. Proactively avoiding trust violations is the best approach. Accordingly, the third contribution is an extended understanding of active trust (Giddens, 1990, 1994; Luhmann, 1988) at the team level. I believe that, in a similar manner as attempts to preserve trust during organizational disruption in the employer-employee relationship (Gustafsson et al., 2020), active and conscious attempts to preserve trust during organizational change are needed at the team level too. If team members cannot actively and consciously protect trust within a team during the change itself, trust may have to be repaired after the change. Without trustpreservation practices or trust-repair practices there is a significant risk that the performance of the work team and the results achieved in the team will also be weakened.

\subsection{Limitations and future research}

Qualitative findings cannot be generalized in a statistical sense. However, this paper has provided an analysis in a change context, and the results are theoretically valuable because they clarify and extend the understanding of existing theory (Yin, 2003). In this study, focus group discussions and interviews proved to be suitable methods, and the information obtained in the discussions was true and clearly described the informants' experiences. Key informants (Tremblay, 1957), the Gioia data analysis procedure (Gioia et al., 2012) and previous theory acted as guidelines to improve the credibility and validity of the data and the robustness of the results (Lincoln and Guba, 1985), and saturation was achieved. 
JOCM 34,5

966

A promising avenue for future research would be to examine the effectiveness of trust-repair mechanisms in an organizational change context while taking into account pre-violation factors. Employees' work engagement, job satisfaction, resilience and stress levels (even additional stress caused by Covid-19) might influence how well individuals and teams can protect and repair trust during and after organizational changes. Furthermore, it is highly recommended that future research quantitatively measure the trust-repair mechanisms identified in this article. This qualitative study developed measurable dimensions of trust-repair at the team level that provide valuable information and insight into the topic, and it would be useful to statistically test and generalize the identified practices to further develop validated trust-repair scale. This research was implemented in the nonprofit Finnish organization. It would be useful investigating trust-repair practices at the team level also in other fields, example in industry or business as well as in other contexts and cultures.

\subsection{Conclusions}

This paper outlined active trust-repair mechanisms at the team level in an organizational change context. The results expand the current theory by presenting novel insights into organizational trust-repair practices at the team level. This study highlights that trust-repair after organizational change takes place in two phases. In the first phase team members' give feedbacks and diagnosis about trust violations can be carried out. In the second phase suitable trust-repair mechanism will implement within team. This study also provides practical information from a real-work context at the team level which can improve managers' and team leaders' understanding of active trust-repair within teams. In addition, this paper contributes to trust-repair literature by proposing promising avenues for future trust-repair research.

\section{References}

Bachmann, R., Gillespie, N. and Priem, R. (2015), "Repairing trust in organizations and institutions: toward a conceptual framework", Organization Studies, Vol. 36 No. 9, pp. 1123-1142.

Costa, A.C., Ferrin, D.L. and Fulmer, C.A. (2017), "Trust at work", in Ones, D., Anderson, N.R., Viswesvaran, C. and Sinangil, H.K. (Eds), The Sage Handbook of Industrial, Work and Organizational Psychology, Sage, London and New York, Vol. 2.

Creswell, J. (2009), Research Design: Qualitative, Quantitative and Mixed Methods Approaches, 3rd ed., Sage Publications, Thousand Oaks, CA.

Dirks, K.T., Lewicki, R.J. and Zaheer, A. (2009), "Repairing relationships within and between organizations: building a conceptual foundation", Academy of Management Review, Vol. 34 No. 1 , pp. 68-84.

Dubois, A. and Gadde, L.E. (2002), "Systematic combining: an abductive approach to case research", Journal of Business Research, Vol. 55 No. 7, pp. 553-560.

Easton, G. (2010), "Critical realism in case study research”, Industrial Marketing Management, Vol. 39 No. 1, pp. 118-128.

Falagas, M.E., Pitsouni, E.I., Malietzis, G.A. and Pappas, G. (2008), “Comparison of PubMed, Scopus, Web of science, and Google scholar: strengths and weaknesses", The Journal of the Federation of American Societies for Experimental Biology, Vol. 22 No. 2, pp. 338-342.

Fulmer, C.A. and Gelfand, M.J. (2012), "At what level (and in whom) we trust -trust across multiple organizational levels", Journal of Management, Vol. 38 No. 4, pp. 1167-1230.

Giddens, A. (1990), The Consequences of Modernity, Polity Press, Cambridge.

Giddens, A. (1994), "Risk, trust, reflexivity", in Beck, U., Giddens, A. and Lash, S. (Eds), Reflexive Modernization, Polity Press, Cambridge, pp. 184-197. 

Gillespie, N. and Dietz, G. (2009), "Trust repair after organization-level failure”, Academy of Repairing trust
Management Review, Vol. 34 No. 1, pp. 127-145.

Gioia, D., Corley, K. and Hamilton, A. (2012), "Seeking qualitative rigor in inductive research-notes on within teams the Gioia methodology", Organizational Research Methods, Vol. 16 No. 1, pp. 15-31.

Guba, E.G. and Lincoln, Y.S. (2005), "Paradigmatic controversies, contradictions, and emerging confluences", in Denzin, N.K. and Lincoln, Y.S. (Eds), The Sage Handbook of Qualitative Research, Sage Publications, New York, pp. 191-215.

Gustafsson, S., Gillespie, N., Hope Hailey, V., Ros, S. and Dietz, G. (2020), "Preserving organizational trust during disruption", Organization Studies, pp. 1-25, doi: 10.1177/0170840620912705.

Kähkönen, T. (2020), "Employee trust repair after organizational change", Journal of Organizational Change Management, Vol. 33 No. 6, pp. 1143-1161, doi: 10.1108/JOCM-05-2020-0136.

Kim, P.H., Dirks, K.T., Cooper, C.D. and Ferrin, D.L. (2006), "When more blame is better than less: the implications of internal vs. external attributions for the repair of trust after a competence- vs. integrity-based trust violation”, Organizational Behavior and Human Decision Processes, Vol. 99 No. 1, pp. 49-65.

Kim, P.H., Cooper, C.D., Dirks, K.T. and Ferrin, D.L. (2012), "Repairing trust with individuals vs. groups", Organizational Behavior and Human Decision Processes, Vol. 120 No. 1, pp. 1-14.

Leavy, P. (Ed.) (2014), The Oxford Handbook of Qualitative Research, Oxford University Press, New York, NY.

Lewicki, R. and Brinsfield, C. (2017), "Trust repair”, Annual Review of Organizational Psychology and Organizational Behavior, Vol. 4 No. 1, pp. 287-313.

Lewicki, R. and Bunker, B.B. (1996), "Developing and maintaining trust in work relationships", in Kramer, R.M. and Tyler, T.R. (Eds), Trust in Organizations: Frontiers of Theory and Research, Sage, Thousand Oaks, CA, pp. 114-139.

Lewicki, R.J., Polin, B. and Lount, R.B. (2016), “An exploration of the structure of effective apologies”, Negotiation and Conflict Management Research, Vol. 9 No. 2, pp. 177-196.

Lincoln, Y. and Guba, E. (1985), Naturalistic Inquiry, Sage, Beverly Hills, CA.

Luhmann, N. (1979), Trust and Power, John Wiley, New York, NY.

Luhmann, N. (1988), "Familiarity, confidence, trust: problems and alternatives", in Gambetta, D.G. (Ed.), Trust, Basil Blackwell, New York, pp. 94-107.

Mayer, R.C., Davis, J.H. and Schoorman, F.D. (1995), “An integrative model of organizational trust", Academy of Management Review, Vol. 20 No. 3, pp. 709-734.

Möllering, G. (2013), "Process views of trusting and crises", in Bachmann, R. and Zaheer, A. (Eds), Handbook of Advances in Trust Research, Edward Elgar, Cheltenham, pp. 285-305.

Morgeson, F.P., Mitchell, T.R. and Liu, D. (2015), "Event systems theory: an event-oriented approach to the organizational sciences", Academy of Management Review, Vol. 40 No. 4, pp. 515-537.

Pate, J., Morgan-Thomas, A. and Beaumont, P. (2012), "Trust restoration: an examination of senior managers' attempt to rebuild employee trust”, Human Resource Management Journal, Vol. 22 No. 2, pp. 148-164.

Rousseau, D.M., Sitkin, S.B., Burt, R.S. and Camerer, C. (1998), "Not so different after all: a crossdiscipline view of trust", Academy of Management Review, Vol. 23 No. 3, pp. 393-404.

Serva, M.A., Fuller, M.A. and Mayer, R.C. (2005), "The reciprocal nature of trust: a longitudinal study of interacting teams", Journal of Organizational Behavior, Vol. 26 No. 6, pp. 625-648.

Six, F. and Skinner, D. (2010), "Managing trust and trouble in interpersonal work relationships: evidence from two Dutch organizations", International Journal of Human Resource Management, Vol. 21 No. 1, pp. 109-124.

Sørensen, O.H., Hasle, P. and Pejtersen, J.H. (2011), "Trust relations in management of change", Scandinavian Journal of Management, Vol. 27 No. 4, pp. 405-417. 
JOCM 34,5

968

Sverdrup, T.E. and Stensaker, I.G. (2018), "Restoring trust in the context of strategic change", Strategic Organization, Vol. 16 No. 4, pp. 401-428.

Tomlinson, E.C. and Mayer, R.C. (2009), "The role of causal attribution dimensions in trust repair", Academy of Management Review, Vol. 34 No. 1, pp. 85-104.

Tranfield, D., Denyer, D. and Smart, P. (2003), "Towards a methodology for developing evidenceinformed management knowledge by means of systematic review", British Journal of Management, Vol. 14 No. 3, pp. 207-222.

Tremblay, M.-A. (1957), "The key informant technique: a nonethnographic application”, American Anthropologist, Vol. 59 No. 4, pp. 688-701.

Webber, S., Bishop, K. and O'Neill, R. (2012), "Trust repair: the impact of perceived organisational support and issue-selling", Journal of Management Development, Vol. 31 No. 7, pp. 724-737.

Weick, K.E. (1995), Sensemaking in Organizations, Sage, London.

Yin, R.K. (2003), Case Study Research: Design and Methods, 3rd ed., Sage Publications, Thousand Oaks, CA.

Zimmermann, A., Raisch, S. and Birkinshaw, J. (2015), "How is ambidexterity initiated? The emergent charter definition process”, Organization Science, Vol. 26 No. 4, pp. 1119-1139.

\section{About the author}

Tiina Kähkönen, MSc (Economics and Business Administration) is a researcher at the LUT School of Business and Management, LUT University, Finland. Her research focuses on the development, preservation and repair of trust, particularly in challenging contexts such as during and after organizational changes. Tiina Kähkönen can be contacted at: tiina.kahkonen@student.lut.fi

For instructions on how to order reprints of this article, please visit our website:

www.emeraldgrouppublishing.com/licensing/reprints.htm

Or contact us for further details: permissions@emeraldinsight.com 